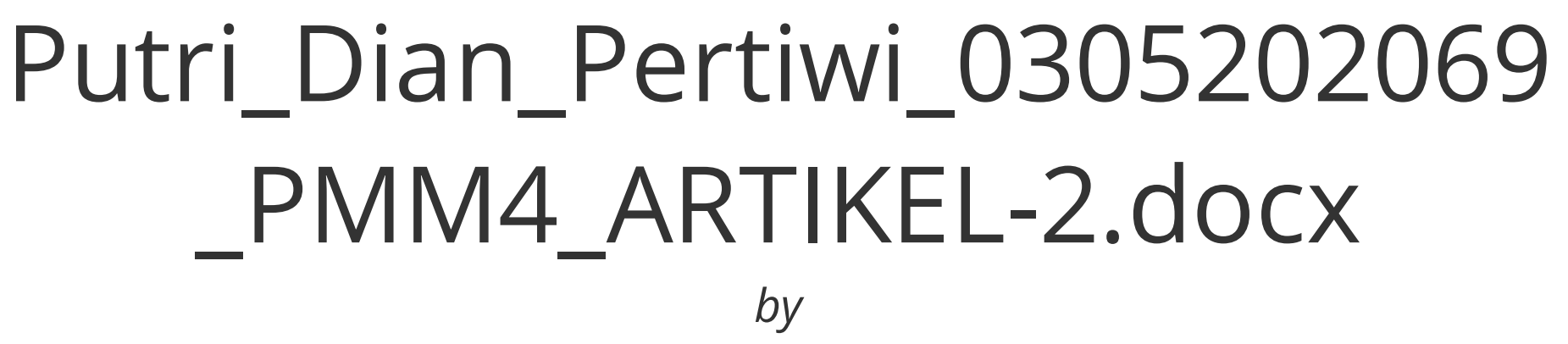

Submission date: 20-Dec-2021 06:59PM (UTC+0700)

Submission ID: 1734203706

File name: Putri_Dian_Pertiwi_0305202069_PMM4_ARTIKEL-2.docx (39.51K)

Word count: 3676

Character count: 25202 


\title{
Efektivitas Blended Learning Model untuk Mahasiswa Algoritma dan Tingkat Memahami di Pemrograman Program The Learning Teknologi Data
}

\author{
Putri Dian Pertiwi (0305202069) \\ Program Studi Pendidikan Matematika
}

Fakultas Ilmu Tarbiyah dan Keguruan UIN Sumatera

Utara JI. William Iskandar Pasar V, Medan Estate

\begin{abstract}
ABSTRAK
Gambaran Umum Penelitian ini bertujuan untuk
\end{abstract}

(1) mengidentifikasi perbandingan motivasi dan tingkat pemahaman. Siswa antara pemodelan blended learning dan pendidikan tradisional, dan

(2), mengakui bahwa penerapan model blended learningmeningkatkan motivasi dan tingkat penjelasan siswa. Jenis penelitian ini adalah eksperimen semu.

Sasaran penelitian adalah PCS STKIPPGRIpontianak yang merupakan Program

Penelitian Pembelajaran Teknologi Data semester II tahun 2013/2014 dan memiliki jumlah mahasiswa sebanyak 270 orang. Sebagai hasil dari penentuan gambar dengan metode sampling yang didedikasikan untuk, total 156 siswa diperoleh. Dalam pengumpulan informasi menggunakan soal tes pilihan ganda dan angket, metode analisis informasi yang digunakan adalah uji-t parametrik siswa dengan taraf signifikansi 0,05. Hasil survei ini menunjukkan bahwa (1) perbandingan blended learningmodeling dan motivasi pendidikan tradisional

adalah 5,782, perbandingan tingkat deskriptif adalah 9,935, dan (2) belajar siswa meningkat. meningkat. Melalui motivasi, kami akan memperkenalkan pendidikan model blended learning secara rata-rata. Peningkatan rata-rata 11.705, penjelasan siswa meningkat, dan peningkatan rata-rata 30.288.

Kata kunci: blended learning, konvensional, motivasi, derajat penjelasan. 


\section{Pendahuluan}

Kemajuan ilmu pengetahuan dan teknologi dalam berbagai bidang kehidupan membawa perubahan, terutama dalam hal peningkatan kualitas pembelajaran. Banyak aspek yang akan mempengaruhi evolusi pembelajaran di masa depan, termasuk pertumbuhan data yang cepatteknologi dan persaingan yang semakin ketat dalam pencari kerja. Hal ini tercermin dari perkembangan teknologi baru yang membutuhkan peningkatan kemampuan. Dalam konteks ini, reformasi di bidang pembelajaran dan pendidikan harus diupayakan secara teratur dan harus merupakan proses yang tidak pernah berhenti. Pembelajaran dan pendidikan berbasis kompetensi merupakan salah satu contoh konsekuensi perubahan yang ditujukan pada peningkatan kualitas pembelajaran dan pendidikan.

Pengembangan bidang pembelajaran diatur dalam Pasal 20, Pasal 3 Tahun 2003Undang-undang Sistem Pembelajaran Nasional (Sisdiknas), dimana pembelajaran nasional berkeyakinan, ditakuti, berakhlak mulia dan sehat dalam konteks pendidikan. Kemauan hidup berbangsa dan bernegara untuk meningkatkan kemampuan peserta didik menjadi warga negara yang berilmu, cakap, kreatif, mandiri, demokratis, dan bertanggung jawab.

Menguasai pentingnya sistem pembelajaran nasional merupakan misi untuk memiliki pesan moral sebagai landasan pembelajaran dan perangkat pelaksana untuk mewujudkan cita-cita perjuangan dalam peradaban negara Indonesia. Pembelajaran vokasi adalah jenjang pembelajaran yang merupakan bagian dari sistem pembelajaran nasional yang meliputi penyiapan tenaga kerja dan peningkatan keterampilan tenaga kerja. kejuruan bertujuan mempersiapkan pembelajaran kerja yang memiliki keahlian serta pengetahuan sesuai dengan kebutuhan lapangan kerja serta mampu meningkatkan kemampuan dirinya dalam menerima serta menyesuaikan diri dengan pertumbuhan teknologi.

Dalam proses pembelajaran yang ditanamkan pada mahasiswa berartinya kemampuan serta teknologi, keahlian bekerja, perilaku mandiri, efektif serta berartinya kemauan bekerja dalam kebutuhan selama hidup. 
Program dan PCST KIP PGRI Pontianac memiliki tujuan yang sama: lulusan kerja di bidang belajar Ini adalah dunia dan memiliki berbagai pengetahuan tentang tumbuhnya dunia pembelajaran. Keberhasilan salah satunya ditentukan oleh keberhasilan proses belajar mengajar. Kemampuan yang diperlukan dari program penelitian teknologi data dan pembelajaran penelitian komputer adalah pemahaman tentang algoritma dan kursus pemrograman. Mata kuliah Algoritma dan Pemrograman merupakan salah satu mata kuliah prasyarat bagi mahasiswa Program Riset Teknologi Data dan PCSTKIPP GRI Pontianak. Algoritma menemukan langkah-langkah untuk memecahkan masalah yang ditempatkan secara sistematis berdasarkan masalah yang harus dipecahkan. Di bidang komputer pribadi, algoritma diperlukan untuk menyelesaikan berbagai masalah tanpa algoritma yang dipikirkan dengan matang hingga proses pemrograman tidak diinginkan, rusak, atau lambat dan tidak efektif. Selain itu, pengetahuan pemrograman membutuhkan keterampilan berpikir seperti analisis, desain, pemikiran analog, penilaian, dan pemikiran (Hadjerrouit, 2007, p.286).

Pencapaian keterampilan siswa dalam proses pendidikan karena menggunakan pendekatan model pendidikan. Model pendidikan yang selama ini dicoba dan diuji adalah model pembelajaran tradisional. Dalam model ini, penyanyi sering disebut sebagai "guru sekolah pusat pembelajaran", mewakili instruktur sebagai aktor / subjek dan siswa sebagai objek. Pandangan tentang transisi dari guru membaca dan membaca-sentris ke siswa membaca dan membaca-sentris sangat didukung oleh pertumbuhan data yang cepat.teknologi. Pembelajaran yang berpusat pada siswa adalah model pendidikan di mana siswa diharapkan menjadi pusat dari proses pembelajaran, di mana siswa proaktif dan mandiri dalam proses pembelajaran, bertanggung jawab untuk mengidentifikasi kebutuhan belajar dan menciptakan sumber data yang sesuai. ada. Dapat menanggapi kebutuhan mereka dan membangun serta menjelaskan pengetahuan mereka berdasarkan 
ditemuinya. Disisi lain, para dosen bergeser guna dari pengajar jadi mitra pendidikan ataupun sebagai fasilitator (dari tutor di tengah menjadi membimbing di samping ).

Dalam proses pembelajaran spesialnya proses belajar mengajar, dosen melaksanakan pendidikan dengan praktik pemakaianmodel pendidikan yang cocok dengan ciri mata kuliah. Pemilihan model pendidikan yang digunakan mempengaruhi mutu serta hasil pendidikan. Sistem pendidikan yang baik menuntut adanya pengembangan, revisi serta pergantian selama masa.

Bersamaan dengan pertumbuhan teknologi yang terdapat, implementasi dari pemanfaatan internet untuk pendidikan salah satunya merupakan e- literasi . Elearning atau Internet memungkinkan pembelajaran mencampurkan tata cara pengajaran serta teknologi sebagai fasilitas dalam belajar. Definisi e- learningini proses belajar secara efisien yang dihasilkan dengan metode mencampurkan penyampaian modul secara digital yang terdiri dari sokongan serta layanan dalam belajar (Barbara, et angkatan laut (AL), 2008, hal. 4).

Komentar Lain pula dikemukan Oleh Seok (2008, p. 5) melaporkan kalau "e- melek huruf adalah baru bentuk pedagogi untuk belajar di abad ke-21.E Preceptor adalah pengembang pendidikan e- learning,

fasilitator perdagangan dan ahli materi pelajaran ". Kelebihan e- learning bisa membagikan fleksibilitas, interaktifitas, kecepatan serta visualisasi lewat bermacam kelebihan dari tiap-tiap teknologi. Selanjutnya diketahui pula sebutan blended literacy ( mongrel literacy) secara simpel bisa didefinisikan sebagai perpaduan tata cara belajar tatap muka (di dalam kelas) dengan modul yang diberikan secara online. Keaksaraan campuran tidak keseluruhan pendidikan dicoba secara online yang belajar tatap muka di kelas, namun berusaha mengatasi serta menanggulangi modul yang belum tersampaikan pada pendidikan dikala siswa belajar di kelas. Bagi Bonk serta Graham (2006, p. 5) mendefinikan campuran dari e- Learning serta pendidikan tatap muka dikelas sebagai berikut Blended Literasi adalah kombinasi dari instruksi dari dua historis yang terpisah model dari les dan belajar Tradi tional melek sistem dan didistribusikan belajar sistem. Ini menekankan cen-netral Bagian dari komputer- didasarkan teknologi di digabung learning. Dosen memakai 
Teknologi pc AKSes DENGAN hearts internet data yang sediakan, Teks Bahan, Dan modul kuliah buat mahasiswa. sebagian dosen membolehkan mahasiswa buat berhubungan satu sama laindengan memakai kemajuan teknik komunikasi asynchronous serta coetaneous. Komunikasi asinkron didefinisikan sebagai instruksi atau komunikasi yang berlangsung diwaktu yang berbeda serta posisi yang berbeda (Fenton \& Watkins, 2010, hlm. 233). Komunikasi coetaneous didefinisikan selaku Instruksi ataupun communication Yang terjalin Beroperasi nyata waktu , Dimana mahasiswa Serta dosen terletak PADA Waktu Yang sama Dan mungkin gede Dari bermacam POSISI (Fenton \& Watkins, 2010, hlm. 240).

sebagian riset sudah menciptakan kalau menggabungkan literasibisa tingkatkan hasil belajar sama dengan atau lebih besar dari siswa yang belajar secara keseluruhan semuanya online, walaupun tingkat keberhasilan bermacam-macam antara disiplin ilmu (Heinze, 2008, hal. 35). Oleh sebab itu tidak mengherankan jika banyak sekolah-sekolah maupun akademi besar sudah melakukan eksperimen model blended literacy . Perihal tersebut pula didukung Oleh komentar Graham (2006, p. 7) Yang mengemukakan "kita bisa menjadi cukup yakin bahwa tren ke arah digabung melek sistem akan meningkat ". Tetapi, wajib dicermati kalau berhasil amalgamated literacytidak otomatis, aspek utama dalam keberhasialan amalgamated literasi adalah pedagogi serta desain instruksional terpaut dengan metode terbaik buat menggunakan alat-alat teknologi, bagaimana interaksi interaksi antara mahasiswa, metode memotivasi mahasiswa, dan mangatur modul yang terbaik di informasikan lewat Internet dibanding tatap muka .

Pelaksanaan blended learning bisa membagikan atensi belajar mandiri mahasiswa sebab banyak data canggih yang bisa diperoleh melalui internet, tata cara ini sangat efektif karena tidak hanya mahasiswa dapat memperoleh perkuliahan tatap muka dengan dosen di kelas, mereka juga dapat mengakses modul yang diberikan secara online di mana saja mereka terletak. Pembelajaran Campuran sangat berguna untuk meningkatkan serta meningkatkan keterlibatan mahasiswa kuliah yang diadakan karena mahasiswa wajib aktif menjajaki pertumbuhan yang terjalin di kampusnya. Pergantian tingkah laku yang mencuat akibat proses belajar merupakan sebagai wujud dari perubahan sikap, anggapan, atau gabungan dari keseluruhan serta 
mutu belajar seorang didetetapkan Dalam mengantarkan modul kuliah dosen memakai media pendidikan berbasis multimedia denganprogram pc yang ditampilkan lewat layar TV proyektor. Keterbatasan perlengkapan yang dipunyai serta banyaknya modul yang wajib di informasikan, menyebabkan tata cara pendidikan di kelas memakai media pendidikan kerap kali tidak bisa dicoba dengan baik.

Dosen difokuskan lebih pada fokus pada modul yang dibebankan pada silabus serta SAP . Perihal ini didukung oleh informasi hasil semester matakuliah Algoritma dan Pemrograman Mahasiswa Program Riset Pembelajaran Data serta Pc semester 2 angkatan 2012 kelas A sore , B pagi, serta C sorerata-rata 47, 943. Kenyataan ini menampilkan kalau mahasiswa belum memiliki pengetahuan yang baik. Skor ratarata untuk nilai yang rendah ini perlunya dilaksanakan inovasi pendidikan Algoritma serta Pemrograman agar mahasiswa dapat tingkatkan hasil belajarnya dengan nilai yang lebih baik. Sehabis mengenali berbagai aspek yang melingkupi serta membatasi pendidikan pada Program Riset Pembelajaran Teknologi Data serta Pc hingga periset mau menemukan cara menemukan lewat pendekatan model pendidikan yang digabungkan keaksaraan untuk tingkatkan motivasi serta tingkat pengetahuan pada mata kuliah algoritma serta pemrograman ProgramRiset Pembelajaran Teknologi Data serta Pc Sekolah Besar Keguruan serta Ilmu Pembelajaran (STKIP) PGRI Pontianak.

\section{sekolah Platform Schoology}

dikembangkan oleh Jeremy Friedman dan Ryan Hwang dari Universitas Washington di St. Louis, Missouri, dan Pasukan Trinidad dari Sekolah Pascasarjana. Akademik. com adalah jaringan sosial kolaboratif untuk sekolah dan lembaga pendidikan besar yang memungkinkan pengguna membuat, mengelola, dan berbagi konten akademik. Akademisi dikenal dengan istilah Education Management System (LMS) atau Course Management System (CMS). Schoology pertama kali dikembangkan untuk berbagi catatan setelah dirilis secara komersial pada Agustus 2009 dan menambahkan fitur tambahan. Pada Oktober 2010, dua atau lebih. Dengan 400 sekolah di semua sistem, kami berencana membuat konten interaktif yang dapat 
digunakan oleh praktisi, mendukung modul pendidikan, dan memberikan akses yang lebih besar bagi orang tua. Schoology menambahkan pemberitahuan Baca berita, aplikasi seluler iPhone dan Android, integrasi Google Documents, aplikasi Google Play, pustaka sumber daya bersama, masalah ujian dan kuis. Pada Desember 2013, sistem Schoology memiliki 35.000 sekolah dan lebih dari 2 juta pengguna. Schoology memiliki konsep yang menggabungkan LMS dan jejaring sosial. Algoritma adalah serangkaian langkah logis untuk memecahkan masalah yang ditempatkan secara sistematis. Bisa dibilang ini adalah proses yang terintegrasi. Atau cara khusus untuk memecahkan masalah nyata. Algoritma ditempatkan secara bertahap secara tertulis, satu per satu, untuk mengakhiri masalah atau masalah. Algoritma pemrograman adalah langkah-langkah yang ditulis secara berurutan untuk memecahkan masalah yang ada dalam pemrograman komputer. Pemrograman sederhana dari algoritme adalah langkah pertama yang perlu Anda buat sebelum Anda menulis program. Masalah yang dipecahkan oleh pemrograman komputer adalah yang berhubungan dengan perhitungan matematis. Menggunakan algoritma untuk menyelesaikan masalah pemrograman memungkinkan siswa untuk lebih memahami konsep algoritma pemrograman sehingga tidak banyak melakukan kesalahan saat menulis program komputer. Pemrograman adalah proses yang digunakan untuk mengimplementasikan suatu algoritma dengan menggunakan bahasa yang sudah ada dalam sistem pemrograman (Budi, 2000: 21). Tujuan dari pemrograman adalah untuk memungkinkan Anda melakukan perhitungan dan melakukan apapun yang Anda inginkan ketika Anda menulis sebuah program. Oleh karena itu, pemrograman membutuhkan pengetahuan tentang algoritma. Kata pemrograman berasal dari kata program. Ini berarti sekumpulan instruksi yang dibuat untuk melakukan fungsi tertentu di komputer Anda. Pemrograman adalah semua aktivitas yang Anda perlukan untuk memprogram di komputer Anda. Sebuah program harus ada agar komputer berfungsi sebagai komputer. Bahasa pemrograman memiliki beberapa karakteristik. 1. Bersiaplah dengan tata bahasa dan aturan khusus saat menulis perintah, struktur program, deklarasi, dan menggunakan penerjemah. 


\section{Motivasi Belajar}

Kata motivasi berasal dari kata latin movere,yang artinya bergerak. Motivasi adalah proses pemberian semangat, arah dan sikap yang berkelanjutan. Singkatnya, sikap termotivasi adalah sikap yang energik, terencana dan tahan lama (Santrock, 2007, p.510). Motivasi dan belajar adalah dua hal yang saling mempengaruhi. Belajar adalah perubahan perilaku yang relatif permanen dan berpotensi terjalin karena penerapan atau peningkatan (peningkatan pelatihan) berdasarkan suatu tujuan untuk mencapai tujuan tertentu. Motivasi berprestasi memegang peranan yang sangat penting. Karena motif siap menggerakkan sikap siswa (gestur wisuda).

Anda dapat belajar dengan penuh semangat dan gembira sehingga pada akhirnya dapat mencapai hasil belajar yang lebih baik.

Dari penjelasan di atas dapat disimpulkan bahwa motivasi berpengaruh terhadap hasil belajar siswa. Motivasi belajar dipengaruhi oleh self-efficacy, lokasi dari kontrol, arah tujuan, usaha, bunga, harga diri, harga diri, dan harga diri sebagai seorang pelajar yang tercantum dalam motivasi penting. Di sisi lain, yang mempengaruhi motivasi eksternal adalah dukungan rumah, praktik penilaian, budaya teman sebaya, pedagogi, kurikulum,

\section{Metode Studi}

Penelitian ini menggunakan desain eksperimen semu (quasi-study) dengan menggunakan desain non original control. Waktu dan Tempat Penelitian Lokasi penelitian berada di Program Penelitian Pembelajaran Teknologi Data Kalimantan Barat dan Sekolah Ilmu Keguruan Komputer (STKIP) PGRI Pontianak. Penelitian ini dilakukan pada bulan Maret hingga April 2013/2014. Tujuan / Topik Penelitian Subyek penelitian ini adalah mahasiswa semester II Program Studi Data Learning dan PC Research tahun ajaran 2013/2014. Intentional slicing, yaitu metode 
pengumpulan 270 mahasiswa dan kemudian metode trial-and-error,

memperhitungkan kesesuaian jadwal kuliah dan gambar dengan pertimbangan

tertentu ketika menentukan gambar-gambar ini. Bagaimana memutuskan. Ilustrasi

yang digunakan dalam penelitian ini adalah empat kelas eksperimen yang terdiri dari total 156 siswa pagi ( 34 siswa) dan sore ( 44 siswa) kelas B. Proses survei prosedural dimulai dengan terlebih dahulu memutuskan kelompok siswa mana yang akan berpartisipasi. Kelompok yang digunakan dalam studi kuasi-eksperimental mengacu pada kelas yang dibuat sebelumnya sebagaikelompok kontrol dan

kelompok eksperimen (Creswell, 2012309). Dalam penelitian ini, kelompok eksperimen menggunakan metode informasi, pengukuran, dan pengumpulan data untuk mengukur efektivitas model literasi terintegrasi dalam melakukan pre-test dan post-test pada kelompok eksperimen dan kontrol. Penerapan model literasi terpadu dapat dilihat dari agregat pra dan pasca tes pada kelompok eksperimen dan kontrol. Informasi kajian berupa nilai motivasi dan tingkat penjelasan. Kuesioner terdiri dari 35 item pernyataan pada Skala Likert, yang berisi 5 alternatif jawaban untuk mengukur kemauan belajar siswa, dan alat tes memiliki 40 item pertanyaan berupa pilihan ganda, termasuk 5 alternatif jawaban. Terdiri dari.

\section{Metode Analisis Data}

Riset ini bertujuan untuk mengenali model daya guna literasi gabungan terhadap tingkat klasifikasi mahasiswa. Setelah dicoba pengujian untuk menguji daya guna yang dirumuskan dalam hipotesis riset. Buat menguji signifikansi pemakaian perbandingan Mean lebih dari 2 kelompok yang berlainan akibat perlakuan pada sesuatu variabel dengan leluasa bisa dicoba dengan uji statistik parametrik memakai uji-t. Saat sebelum melaksanakan uji statistik parametrik, informasi yang kita peroleh wajib memiliki syarat-syarat yang harus dikerjakan pengujiannya dengan parametrik uji antara lainmerupakan berdistribusi wajar serta homogen. Jika informasi tersebut penuhi persyaratan mencoba hipotesis dengan parametrik uji, tetapi apabila tidak penuhi persyaratan hingga uji hipotesis dengan non parametrik. 


\section{Hasil dan Penelitian Temuan}

Diskusi Hasil analisis Hipotesis 1 menggunakan informasi tentang motivasi tertinggi kelas tes dan kontrol. Informasi tersebut telah lulus uji persyaratan analitis dan dinyatakan terdistribusi secara adil dan merata. Untuk Hipotesis 1, kami menggunakan uji-t dengan tingkat signifikansi 0,05 . Tabel 1 menunjukkan ringkasan hasil perhitungan. Motivasi kelas tes dengan kelas kontrol memiliki nilai signifikansi $0,000 \& 1 t$; Signifikansi $(\alpha) 0$,

.. Hasil analisis hipotesis keempat menggunakan fakta hasil pre-test dan post-test pembelajaran gabungan kemahiran. Data telah lulus uji analisis prasyarat, dilaporkan dalam hari, dan variansnya seragam. Hipotesis keempat diuji dengan menggunakan uji paired sample t-test. Hasil uji hipotesis ini ditunjukkan pada Tabel 4.

Berdasarkan hasil hipotesis empat penggunaan taraf signifikansi diperoleh bahwa terdapat peningkatan tingkat pemahaman mahasiswa pada mata kuliah algoritma dan penerapan penerapan pembelajaran combine mastering, dengan nilai signifikansi sebesar $<$ signifikansi $(\alpha)$. Tingkat rata-rata skor pemahaman yang diukur sebelum studi gabungan adalah28.462. Setelah belajar dengan belajargabungan dalam 7 sesi, tingkat pemahaman yang diukur kembali, dan motivasi belajar rata-rata adalah58.750 poin atau setara dengan peningkatan rata-rata 30.288 poin.

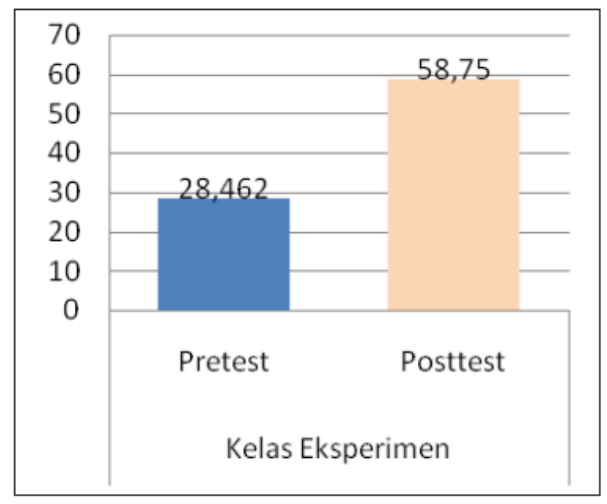

Gambar 5 menunjukkan peningkatan rata-rata pemahaman. Tujuan penelitian, pembahasan dalam analisis data, ditujukan untuk menguji hipotesis untuk fakta empiris yang 
valid . Hipotesis 1 dan 2 umumnya perlu memberikan dasar yang kuat untuk pengambilan keputusan mengenai Hipotesis 3dan 4. Hal ini karena dampak penerapan blended learning dibandingkan dengan pembelajaran tradisional dapat membuat perbedaan besar dalam motivasi dan pemahaman siswa di kedua kelas. Berdasarkan hasil analisis tersebut akan dilakukan pembahasan sebagai berikut. Hasil dari hipotesis pertama diperoleh nilai signifikansi sebagai berikut, berdasarkan perbedaan algoritma dan motivasi belajar mahasiswa pada mata kuliah pemrograman setelah mengikuti pembelajaran versi pembelajaran kombinasi dengan pembelajaran versi tradisional. Rata-rata motivasi belajar siswa memperoleh nilai kurang dari Perbedaan rata-rata motivasi akhir antara kelas eksperimen dan kelas kontrol adalah. Perbedaan motivasi belajar siswa dalam varian yang memadukan belajar dan belajar dapat diamati pada aktivitas siswa.

15 Hal ini terlihat dari partisipasi dan perhatian siswa terhadap proses pembelajaran. Lingkungan belajar eksternal seperti media, materi, dan wacana yang disiapkan dapat membangkitkan minat dan potensi belajar siswa, yang mendukung munculnya atau Hal ini dapat dilihat dari partisipasi dan perhatian siswa dalam proses pembelajaran. Pengaturan pembelajaran eksternal seperti media , materi, dan wacana yang disiapkan dapat membangkitkan minat dan potensi belajar siswa, yang mendukung munculnya atau tumbuhnya motivasi internal. Nilai kurang dari. Terdapat perbedaan rata-rata pemahaman kelas eksperimen (post-test) karena rata-rata pemahaman kelas eksperimen (post-test) adalah dan rata-rata pemahaman kelas eksperimen (post-test) adalah. Dan itu mengontrol9.936 kelas. Perbedaan pemahaman siswa terlihat pada peningkatan rata-rata pemahaman siswa pada eksperimen kelas yang lebih tinggi dibandingkan dengan kelas kontrol. Meningkatkan dan mengatasi materi yang tidak dikomunikasikan dalam pembelajaran di kelas mengembangkan partisipasi mahasiswa dalam perkuliahan yang diberikan, karena mahasiswa aktif mengikuti perkembangan kampus ketika menguasai dan pembelajaran harus digabungkan. membantu memuji. Media online berbasis webmenyediakan soal latihan dan kuis. Ini tersedia untuk siswa karena komentar langsung terlihat dalam bentuk skor yang diterima, termasuk jawaban yang benar dan salah untuk pertanyaan tersebut. Ini membantu siswa memahami masalah serius. Karena mereka memiliki wajah, itu menginspirasi mereka untuk belajar. Kembali aktif bekerja untuk meningkatkan kualitas 
pembelajaran.

Ketiga, berdasarkan hasil Hipotesis III, kemauan belajar mahasiswa pada mata kuliah algoritma dan pemrograman memiliki perbedaan yang signifikan \& 1t;. Rata-rata skor motivasi awal sebelum pembelajaran penguasaan majemuk adalah120.449. Setelah menerapkan 000 \& 1t;. Rata-rata skor motivasi awal sebelum pembelajaran penguasaan majemuk adalah120.449. Setelah menerapkan 000 \& 1t;. Rata-rata skor motivasi awal sebelum pembelajaran penguasaan majemuk adalah120.449. Setelah menerapkan gabungan penguasaan versi pembelajaran untuk tujuh sesi, rata-rata skor motivasi belajar adalah 132.154, dengan peningkatan rata-rata11.705.

Secara umum varian yang dipadukan dalam proses pembelajaran memberikan pengaruh yang signifikan pada motivasi siswa. Studi gabungan ini memberikan siswa lebih banyak ruang untuk mengeksplorasi keterampilan dan kemandirian mereka dengan fokus pada kegiatan belajar di kelas. Blended learning adalah kombinasi pembelajaran tatap muka dan penguasaan online yang menciptakan interaksi dinamis antara siswa dan praktisi, dan antara siswa dan siswa, dan mendorong siswa untuk belajar melalui penggunaan metode pembelajaran yang beragam dan disukai. meningkat. Keempat, Menguasai, dengan signifikansi \& 1 lt; $(\alpha)$, berdasarkan hasil Hipotesis IV bahwa penerapan pembelajaran kompleks meningkatkan pemahaman mahasiswa pada mata kuliah algoritma dan pemrograman. Tingkat ratarata skor pemahaman yang diukur sebelum studi gabungan adalah28.462. Setelah belajar dengan gabungandalam tujuh sesi pemahaman yang diukur kembali, dengan rata-rata motivasi belajar58.750, naik rata-rata30.288. Modelpembelajaran yang kompleks mengacu pada penggunaan Internet untuk menyediakan berbagai solusi yang dapat meningkatkan pengetahuan dan keterampilan Anda. Optimalkan peran komputer Anda sebagai sarana untuk menampilkan dan memanipulasi teks, grafik, dan suara pada tampilan yang terintegrasi. Teknologi information memungkinkan Siswa untuk review belajar bagaimana belajar ( discover belajar jalan ). Dalam penguasaan komplekspembelajaran, sumber daya tersebut tidak terbatas pada sumber daya pendidikan yang dimiliki sendiri-mata oleh pengajar, sehingga banyak sumber belajar yang perlu diakses oleh siswa. Hal ini juga perlu didukung dengan kemampuan praktisiuntuk merancang sumber belajar mana yang dapat diakses untuk dikombinasikan dengan buku, multimedia dan sumber belajar lainnya. Pemberian 
materi mandiri kepada siswa yang diberikan alokasi waktu untuk pelatihan, dan materi yang memerlukan penjelasan khusus diberikan waktu waktu kehadiran, sehingga pembelajaran juga hemat waktu. Pembelajaran tatap muka juga membantu untuk mengevaluasi pembelajaran antara siswa dan praktisi . Siswa belajar sesuai dengan gaya dan kecepatan belajar mereka di bawah bimbingan seorang instruktur yang memfasilitasi dan menyelesaikan seluruh proses pembelajaran.

\section{Kesimpulan}

Berdasarkan temuan yang dipaparkan pada bab sebelumnya, dapat dikatakan bahwa Pertama, motivasi mahasiswa mempelajari programdan pemrograman di STKIP PGRI Pontianak pada pendidikan ilmu komputer dan komputer yahoo sangat berbeda antara kelas yang menggunakan model pembelajaran campuran dan kelas menggunakan model tradisional. Kedua, STKIP PGRI Pontianakpemahaman mahasiswa mata kuliah algoritmik dan pemrograman di Teknologi Informasi dan Pendidikan Komputasi secara signifikan antara kelas yang menggunakan model pembelajaran campuran dan kelas yang menggunakan model tradisional. Ketiga, motivasi belajar ilmu komputer dan pedagogi komputer pada mata kuliah algoritma dan pemrograman STKIP PGRI Pontianac sangat meningkat dengan penggunaan model blended literacy .

Keempat, pemahaman mahasiswa mata kuliah algoritma dan pemrograman mata kuliah STKIP PGRI Pontianak Pendidikan Teknologi Informasi dan Komputer sudah sangat meningkat dengan penggunaan model blended literacy .

\section{DAFTAR PUSTAKA}

Abroto, Maemonah, \& Ayu,NP (2021). Pengaruh Metode Blended Learning Dalam meningkatkan Motivasi Dan Hasil Belajar Siswa Sekolah Dasar.

Edukatif Jurnal Ilmu Pendidikan, 3 (5), 1993 - 2000.

Https//Doi.Org/Https//Doi.Org/10.31004/Edukatif.V3i5.703

Armin, \& Abrar,A. (2015). Blended Learning, ImplementasiE-Learning Di Politeknik Negeri Balikpapan.

Jurnal Sains Terapan, 1 (1), 48 - 53. Http//Jurnal.Poltekba.Ac.Id/Index.Php/ Jst/ Issue / 
View / 7

Bibi,S. (2015). Efektivitas Penerapan Blended Learning Mata Pelajaran Algoritma Dan Pemrograman. Jurnal Pendidikan Informatika Dan Sains, 4 (2), 274 286.

Bibi,S., \& Jati,H. (2015). Efektivitas Model Blended Learning Terhadap Pelajaran Algoritma Dan Pemrograman. Jurnal Pendidikan Vokasi, 5 (1), 74 - 87.

15

Dakhi,O., Jama,J., Irfan,D., Ambiyar, \& Ishak. (2020). Blended Learning Sebuah Model Pembelajaran Abad 21 Di Perguruan Tinggi. International Journal Of Multi Science, 1 (7), $17-23$.

Diana,PZ, Wirawati,D., \& Rosalia,S. (2020). Blended Learning Dalam Pembentukan Kemandirian Belajar. Alinea Jurnal Bahasa, Sastra, Dan Pengajaran, 9 (1), 16 - 22. Https//Doi.Org/10.35194/Alinea.V9i1.763

Fandianta, Sanjaya,GY, \& Widyandana. (2018). peningkatan Pengetahuan Mahasiswa Dengan Memberikan Fleksibilitas Belajar Melalui Metode BlendedSedang belajar. Jurnal Pendidikan Kedokteran Indonesia, 2 (2), 1 -8 .

Gawise, Tarno, \& Lestari, Ayu,A. (2021). Efektifitas Pembelajaran Model Flipped Classroom Masa Pandemi Covid-19 Terhadap Hasil Belajar Di Sekolah Dasar. Edukatif Jurnal Ilmu Pendidikan, 3 (1), 246 - 254.

Hatmo,SHD (2021). Dampak Pandemi Covid-19 Terhadap Efektivitas Pembelajaran Jarak Jauh Secara Daring. Scholaria Jurnal Pendidikan Dan Kebudayaan, $11(2), 115-122$.

Herliandry,LD, Nurhasanah,N., Suban,ME, \& Kuswanto,H. (2020). Pembelajaran Pada Masa Pandemi Covid-19. JTP-Jurnal Teknologi Pendidikan, 22 (1), 65 70. Https//Doi.Org/10.21009/Jtp.V22i1.15286

Maiti, \& Bidinger. (2020). Dampak Pandemi Covid-19 Terhadap Penerapan Pembelajaran Daring Di Sekolah Dasar. Jurnal Informasi Dan Pemodelan Kimia, 53 (9.

Ningtiyas,PW, \& Surjanti,J. (2021). Pengaruh Self Regulated Learning Dan Self Efficacy Terhadap Hasil Belajar Ekonomi Peserta Didik Dalam Learning Daring Di Era Covid-19. EDUKATIF JURNAL ILMU PENDIDIKAN, 
$3(4), 1660-1668$.

Https//Doi.Org/Https//Doi.Org/10.31004/Edukatif.V3i4.630

Nopitasari,E., Rahmawati,FP, \&. (2021). Peningkatan Hasil Belajar Matematika

Melalui Model Pembelajaran Blended Learning Berbasis Blog Pada

Peserta Didik Di Sekolah Dasar. Edukatif Jurnal Ilmu ..., 3 (5), 1935 -

1941. Https//Edukatif.Org/Index.Php/Edukatif/Article/View/699

16 
Putri_Dian_Pertiwi_0305202069_PMM4_ARTIKEL-2.docx

ORIGINALITY REPORT

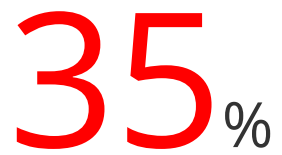

SIMILARITY INDEX

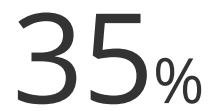

INTERNET SOURCES
$7 \%$

PUBLICATIONS
$28 \%$

STUDENT PAPERS

PRIMARY SOURCES

1 journal.uny.ac.id

Internet Source

2 Submitted to Program Pascasarjana

Universitas Negeri Yogyakarta

Student Paper

3 algoritmapencarian.blogspot.com

Internet Source

4 journal.ikippgriptk.ac.id

Internet Source

5 jurnal.uinsu.ac.id

Internet Source

6 Submitted to Universitas Negeri Semarang Student Paper

7 journalfkipunipa.org

Internet Source

8 smkkotadijawatimur.wordpress.com 

terhadap keterampilan berpikir kreatif dalam pembelajaran fisika terapan", Jurnal

Pendidikan Fisika dan Keilmuan (JPFK), 2019

Publication

11

repository.uinsu.ac.id

12 repository.upi.edu

13 text-id.123dok.com

14 venusonline.wordpress.com Internet Source

15 Lidya Angie Widyasari, Mohamad Arief Rafsanjani. "Apakah Penerapan Blended Learning Dapat Meningkatkan Motivasi dan Hasil Belajar Siswa dalam Pembelajaran Jarak Jauh?", EDUKATIF : JURNAL ILMU PENDIDIKAN, 2021

Publication 
Exclude bibliography On 